Darja Mihelič Znanstvenoraziskovalni center Slovenske akademije znanosti in umetnosti Novi trg 2, SI-1000 Ljubljana

mihelic@zrc-sazu.si

\title{
Sporazumi o mejah srednjeveških mestnih teritorijev (Piran in njegovi sosedje)
}

\author{
Izvorni znanstveni rad | Original scientific paper \\ UDK 930.255:332.2(094.9)>(497.4 Piran)"652" \\ Primljeno: 29. IX. 2010.
}

\section{Izvleček}

Raziskava temelji na ohranjenih rokopisih piranske izpostave Pokrajinskega arhiva Koper iz 13. in prvih desetletij 14. stoletja, ki opisujejo reševanje ozemeljskih sporov in določanje mejà srednjeveškega Pirana s sosedi. Večino listin je objavil Camillo De Franceschi, eno Pietro Kandler, nekaj pa ni objavljenih.

\section{Izvadak}

Istraživanje se zasniva na sačuvanim rukopisima piranske podružnice Pokrajinskog arhiva u Kopru iz 13. i prvih desetljeća 14. stoljeća koji opisuju rješavanje zemljišnih sporova i određivanje međa srednjovjekovnoga Pirana sa susjedima. Većinu je listina objavio Camillo De Franceschi, jednu Pietro Kandler, a ima i neobjavljenih.

Ključne besede: srednji vek, severozahodna Istra, srednjeveška mesta, meje, Piran, Buje, Izola Key words: Middle Ages, north-western Istria, medieval towns, borders, Piran, Buje, Izola 


\section{Uvod}

Izbrano temo pogojuje več razlogov. Problematika zgodovine dogovorov o mejah je v medsosedskih odnosih med Republiko Slovenijo in Republiko Hrvaško dokaj aktualna. V prostorskem pogledu pa je predmet obravnave Istra, ki ji je revija namenjena, podrobneje njeno ožje severozahodno območje, ki je jabolko spora v političnih razpravah obeh držav. Osvetliti želimo, kako so mejna vprašanja na tem območju reševali pred sedmimi stoletji.

$\mathrm{V}$ srednjem veku je (severo)zahodna Istra izkazovala pestro urbano podobo, ki se je izoblikovala na temelju antičnih in zgodnjesrednjeveških naselbin. ${ }^{1}$ Te niso bile omejene na prostor gosto pozidanega urbanega jedra, ampak je k njim spadal še del okoliškega zaledja. Mestna ozemlja so - podobno kot dandanes občinska - marsikje mejila neposredno drugo na drugega. Lastniška struktura znotraj in zunaj naselbin je bila v srednjem veku dokaj pestra - v njej so bili udeleženi istrski mejni grofje, oglejski patriarhi, andeški ${ }^{2}$ in goriški ${ }^{3}$ grofje, freisinški, ${ }^{4}$ tržaški, koprski, novigrajski škofje in druge cerkvene skupnosti, nekateri drugi fevdalni gospodje, vplivne družine iz Benetk ter drugih mest itd. Vzlic spremembam oblasti v Istri, vplivu istrskih oblastnikov in različnih zemljiških gospodov ter prepleteni posestni strukturi, so mestne naselbine uspešno izgrajevale svojo avtonomijo in dosegle status mestnih državic z dokajšnjo stopnjo samouprave. Ta se je odražala v uglednih domačih meščanih kot nosilcih mestnih oblastnih in upravnih funkcij, svoj izraz pa je našla v elitnem zakonskem aktu - statutu. Urejal je mestno upravo, javni red in mir ter družinsko in gospodarsko življenje v mestu in njemu pripadajočem okolišu.

Mala mestna državica je - podobno kot sodobna nacionalna država vselej skušala varovati lastne interese in si v razmerju do nasprotne/konkurenčne strani prizadevala izpogajati ugodnost ali prednost. Vsak subjekt, ki je mesto ogrožal ali mu konkuriral od zunaj, najsi je šlo za sosednje mesto,

1 Bernardo Benussi, Nel medio evo, Pagine di storia istriana, Parenzo 1897, passim; ponatis: Rovigno-Trieste 2004. (Collana degli Atti, Centro di ricerche storiche - Rovigno, 23); idem, L'Istria nei suoi due millenni di storia, Trieste 1924, passim; ponatis: Venezia-Rovigno 1997. (Collana degli Atti, Centro di ricerche storiche - Rovigno, 14); Egidio Ivetic (ur.), Istra kroz vrijeme, Pregled povijesti Istre sa osvrtom na grad Rijeku, Rovinj / Rovigno-Rijeka / Fiume-Trst / Trieste 2009. (Collana degli Atti, Centro di ricerche storiche-Rovigno, 30).

2 Darja Mihelič, "Srednjeveška posest freisinške škofije v Istri” / "Der mittelalterliche Besitz des Hochstifts Freising in Istrien”, v: Blaznikov zbornik / Festschrift für Pavle Blaznik, ur. Matjaž Bizjak, Ljubljana-Škofja Loka 2005. (Loški razgledi, Doneski, 11), 61-73, 67-81.

3 Peter Štih, Goriški grofje ter njihovi ministeriali in militi v Istri in na Kranjskem, Ljubljana 1994 (dopolnjen ponatis 1997). (Razprave Filozofske fakultete); idem, Studien zur Geschichte der Grafen von Görz, Die Ministerialen und Milites der Grafen von Görz in Istrien und Krain, Wien-München 1996. (Mitteilungen des Instituts für Österreichische Geschichtsforschung, Ergänzungsband, 32).

4. Mihelič, idem. 
zemljiškega gospoda, nadrejeno cerkveno ali svetno oblast, so meščani občutili kot neprijateljski tujek. Meščani so v takih razmerah izgrajevali močan občutek pripadnosti svojemu mestu in oblikovali lastno identiteto.

Zlasti skrbno so mesta varovala svoje ozemlje. Na mejah s sosedi je pogosto prihajalo do sporov glede pripadnosti zemljišč tej ali oni strani. Načini reševanja ozemeljskih sporov sosednjih mestnih državic pa kažejo sorodne poteze s sodobnimi meddržavnimi dogovori. Pri reševanju mejnih vprašanj so že v srednjem veku poznali takó skupine pogajalskih izvedencev (današnje “ekspertne skupine”), kot odločanje s pomočjo izbranih razsodnikov-mediatorjev in zunanjih arbitrov, pa tudi dogovore na "premierski” ravni (mestnih glavarjev).

Pogled v preteklost in poduk iz nje sta manj boleča kot čas, ki ga v medsosedskih odnosih doživljamo danes. Zato se ne zdi odveč osvetliti drobec tovrstnih poglavij istrske zgodovine, saj nam morda prav ti kažejo možnosti sporazumnih rešitev glede spornih mejnih vprašanj, ki tarejo Republiko Slovenijo in Republiko Hrvaško. Če poznamo zgodovino, se je težko izogniti vtisu, da bi bili zapleti morda že rešeni, če se vanje s svojimi zdraharskimi interesi ne bi vpletale posamezne osebe na politični sceni, ki z namenom nabiranja političnih točk delujejo predvsem na hujskaški ravni in redko razpolagajo z zadostnim zgodovinskim védenjem.

Raziskava temelji na ohranjenih zapisih piranskega mestnega arhiva 13. in prvih desetletij 14. stoletja. Arhiv je sedaj vključen v Pokrajinski arhiv Koper (SI PAK PI). ${ }^{5}$ Listine, ki so ohranjene v rokopisu, je objavil Camillo De Franceschi v svojem Chartularium Piranense, ${ }^{6}$ eno Pietro Kandler v Codice diplomatico istriano, ${ }^{7}$ nekaj pa ni objavljenih. Piran se je - sodeč po znanih zapisih o določanju medsebojnih mejà, ozemeljskih sporih in dogovarjanjih s

5 Posebni mestni arhiv (Archivio civico antico) v Piranu je bil ustanovljen 1877. Tega leta so podrli občinsko poslopje, kjer so se hranile arhivalije; prenesli so jih v Kazino. Prvi arhivar je bil Stefano Rotta. Kasneje se je arhiv združil s piransko mestno knjižnico. Domenico Vatta je bil (1891) hkrati mestni bibliotekar in kustos arhiva. 1895 je bil arhiv prestavljen v severni del kasnejšega sodnega poslopja, 1954 pa skupaj z mestno knjižnico v stavbo Mestnega muzeja. Do 1955 je arhiv ostal v sklopu mestne knjižnice, tedaj pa je bil ustanovljen Mestni arhiv, ki je bil 1974 pridružen Pokrajinskemu arhivu Koper. Leto kasneje, 1975 se je arhiv preselil v minoritski samostan v Piranu. Slabo stanje prostorov je bilo vzrok, da je v osemdesetih letih prišlo do selitve dela arhivalij v Koper. Leta 1995 je stari piranski arhiv dobil prostore na Župančičevi 4 v Piranu, od koder so ga julija 2008 preselili na Fornače 33, novembra 2009 pa v Studio Galerijo Gasspar na Savudrijski ulici 5 v Piranu.

6 Camillo de Franceschi, Chartularium Piranense, Raccolta dei documenti medievali di Pirano, I. (1062-1300), Parenzo 1924. (Atti e memorie della Società istriana di archeologia e storia patria, 36); idem, "Chartularium Piranense, Raccolta dei documenti medievali di Pirano, II. (1301-1350)", Atti e memorie della Società istriana di archeologia e storia patria, 43, Pola-Parenzo 1931, 19-96 (št. 1-39); idem, ibidem, 44, Pola-Parenzo 1932, 271-320 (št. 40-65) (v nadaljevanju: CP I, CP II).

7 Pietro Kandler, Codice diplomatico istriano, 1-3, Trieste 1986. (riproduzione) (v nadaljevanju: CDI). Gre za listino, objavljeno pod N. 295. 
sosednjimi mestnimi naselbinami - največkrat soočal s sosednjo Izolo, ${ }^{8}$ sledile so Buje, ${ }^{9}$ občasno pa je bilo potrebno reševati tudi mejna vprašanja z Umagom. ${ }^{10}$ "Sožitje" z Izolo in Bujami je predpisoval tudi piranski statut. ${ }^{11}$

V nadaljevanju si bomo najprej ogledali, v kakšnih okoliščinah je prihajalo do podrobnejšega določanja mejà in razčiščevanja vprašanj v zvezi z njimi ter kdo je dejavno posegal v razmejevanje, sledil bo primer srednjeveškega opisa (piranskih) komunalnih mejà, nato pa se bomo podrobneje posvetili zapisom, ki so nastali v zvezi z razmejitvami med Piranom in Bujami.

\section{Kdo in kdaj je razsojal o mejah?}

Določanje mejà istrskih mestnih naselbin je pogosto sledilo spremembam oblasti. Novi oblastniki so radi posegali v medmestne spore in na ta način dokazovali in utrjevali svojo avtoriteto nad mesti.

Po odstavitvi istrskega mejnega grofa Henrika IV. iz družine Andechs je januarja 1209 prejel mejno grofijo Istro oglejski patriarh Wolfger (12041218). ${ }^{12}$ Ta je 20. maja 1212 osebno prišel v Sečovlje in ob strinjanju v polnem številu prisotnih piranskih konzulov (visoki člani mestne uprave s sodnimi pristojnostmi) in gastaldov (mestni glavarji) s soglasjem koprskih in izolskih gastaldov in konzulov ter zbranih ljudi izbral pet dobrih in razsodnih mož (dva iz Trsta in tri iz Umaga), ki so prisegli, da bodo pošteno in brez zvijače določili mejo med Piranom in Izolo. Delo so tudi opravili. Piranski konzuli,

8 SI PAK PI 9.1 Notarske pergamentne listine: 1212, 20. 5., Sečovlje (kopija iz 1296, objava: CP I, št. 69); 1254, 18. 9., Cetore (CP I, št. 91); 1254, 9. 10., Koper (CDI, N. 295); 1255, 7. 7., Nožed (CP I, št. 93); 1255, 26. 7., med Piranom in Izolo (CP I, št. 94); 1283, 3. 8., Piran (CP I, št. 172); 1283, 3. in 4. 8., med Piranom in Izolo (CP I, št. 173); 1283, 6. 8., Izola (CP I, št. 174); 1283, 6. 8., Izola; 1285, 13. 8., Piran; 1285, 8. 10., Koper (CP I, št. 184); 1285, 19. 10., Koper (CP I, št. 185); 1285, 8. in 19. 10., Koper (kopija obeh prejšnjih dokumentov); 1303, 24. 6., Piran (CP II, št. 9); 1303, 25. 6., Izola (CP II, št. 10); 1315, 2. 8., Koper (CP II, št. 32); 1315, 2. 8., Koper (CP II, št. 33); 1320, 11. 8., Izola (CP II, št. 38); 1321, 29. 8., San Basso (CP II, št. 43).

9 SI PAK PI 9.1 Notarske pergamentne listine: 1212, ?. 5., čistina de Loçe (kopija iz 1300, 3. 2., objava: CP I, št. 70); 1295, 17. 5., Piran (CP I, št. 220); 1295, 1. 11.-1296, 1. 2., Piran (CP I, št. 22 1); 1301, 18. 3., med Piranom in Bujami (CP II, št. 1); 1306, 2. 2. (CP II, št. 16); 1306, 14. 2., Buje; 1306, 27. 2., med Bujami in Piranom; 1306, 6. 3., Piran (CP II, št. 17); 1306, 25. 4., Buje (CP II, št. 18); 1306, 1. 5., Piran (CP II, št. 19); 1306, 7. 5., Piran (CP II, št. 20); 1306, 23. 5., Piran (CP II, št. 21); 1306, 4. 6., savudrijski Kras (CP II, št. 22); 1306, 12. 6., Poreč (CP II, št. 23); 1306, 16. 6., Buje (CP II, št. 24); 1306, 20. 6., savudrijski Kras (CP II, št. 25); 1320, 5. 8., Piran (CP II, št. 37).

10 SI PAK PI, 9.1 Notarske pergamentne listine: 1281, 9. 10., savudrijski Kras (CP I, št. 163).

11 Piranski statut iz 1307 je v tretjem členu osme knjige predpisoval, da ne sme noben piranski meščan ali prebivalec Sečovelj prodati ali dati seno ali travo meščanom ali prebivalcem Izole, niti jim ne sme dovoliti, da bi na Piranskem imeli družbo (societas) za oranje ali z voli; tujcem iz Istre ni smel prodati sena ali trave, če niso prišli pred podestata in prisegli, da potrebujejo seno zase in da ne bodo omogočili, da bi prišlo v roke Izolanom (Camillo de Franceschi (ed.), Gli statuti del comune di Pirano del 1307 confrontati con quelli del 1332 e del 1358, Venezia 1960., 108-109). Enajsti člen devete knjige statuta je Bujčanom, ki bi s Pirančani sklenili družbo z živino (socida), prepovedoval, da bi hodili obdelovat piransko ozemlje ali da bi tam uredili obor za živino ali dvorišče (ibidem, 135). Za socido, prim. Darja Mihelič, "Socida v Piranu od 1280 do 1340", Slovensko morje in zaledje, 2/3, 1979, 63-78.

12 Heinrich Schmidinger, Patriarch und Landesherr, Die weltliche Herrschaft der Patriarchen von Aquileja bis zum Ende der Staufer, Graz-Köln 1954, 88-89. 
gastaldi in prebivalstvo so pred patriarhom v svojem in v imenu svojih komun potrdili določitev meje. Tudi patriarh se je s soglasjem prisotnih kanonikov oglejskega kapitlja zavezal razmejitev spoštovati. ${ }^{13} \mathrm{~V}$ istem mesecu maju je patriarh Wolfger razsodniško posegel tudi v spor med Piranom na eni ter Bujami in Kaštelom na drugi strani. Trije izbrani razsodniki, po eden iz Umaga, Pirana in Buj, so popisali mejo, piranski, bujski in tudi umaški konzuli in gastaldi ter ostali prisotni pa so v imenu svojih komun pristali na njihovo določitev meje. Tudi patriarh se je obvezal, da jo bo upošteval. ${ }^{14}$

Le nekaj let po svojem nastopu se je vpletel v piransko-izolski mejni spor, v katerem je imel Piran vlogo tožnika, tudi patriarh Gregor de Montelongo (1251-1261). Za razsodnika je pooblastil Landa de Montelongo, podestata (mestni glavar) Kopra. Ta je bil morda patriarhov sorodnik, vsekakor pa je bil tudi v funkciji koprskega podestata na zelo visokem položaju. Koper je v tem času ob podpori patriarha užival velik vpliv tako v odnosu do Trsta, kot do sosednjih obalnih in celinskih istrskih mest. Podestat je v prisotnosti številnih prič iz različnih krajev in predstavnikov obeh sprtih strani s pooblastilom koprske in piranske podestarije in istrske rihtarije (rictaria $)^{15} 18$. septembra 1254 po nasvetu koprskih modrecev določil mejo med piranskim in izolskim območjem. ${ }^{16}$

Leto kasneje je bil s strani piranske in izolske komune $\mathrm{v}$ odsotnosti izbran za arbitra-mediatorja (iudex arbitralis et amicabilis compositor) koprski podestat Marcus Çenus, ${ }^{17}$ slabe tri tedne kasneje pa je tudi dejansko nastopil kot razsodnik med Piranom in Izolo causa litis vertentis inter communia predictarum terrarum... volentes evitare multa malla et scandala. ${ }^{18}$

V 13. stoletju (od 1267 dalje) so Benetke razširile svojo oblast nad številnimi istrskimi mesti. Najvišji oblastnik v mestu - mestni podestat je bil v mestih pod beneško oblastjo Benečan, imenovala pa ga je Serenissima. Koper se je predal Benetkam 1279, akt predaje Pirana pa je datiran s 26. januarjem $1283 .{ }^{19}$

13 SI PAK PI 9.1 Notarske pergamentne listine: 1212, 20. 5., Sečovlje (kopija iz 1296, objava: CP I, št. 69).

14 SI PAK PI 9.1 Notarske pergamentne listine: 1212, ?. 5., čistina de Loçe (kopija iz 1300, 3. 2., objava: CP I, št. 70).

$15 \mathrm{Na}$ čelu Istre je bil patriarhov namestnik, generalis gastaldio z vrhovnimi sodnimi in oblastnimi kompetencami deželnega gospoda. Kasneje se je zanj uveljavil vzdevek richtarius, ki pa ga je kmalu nadomestil naziv marchio, prim. Schmidinger, ibidem, 151-152.

16 SI PAK PI 9.1 Notarske pergamentne listine: 1254, 18. 9., Cetore (CP I, št. 91); 1254, 9. 10., Koper (CDI, N. 295).

17 SI PAK PI 9.1 Notarske pergamentne listine: 1255, 7. 7., Nožed (CP I, št. 93).

18 SI PAK PI 9.1 Notarske pergamentne listine: 1255, 26. 7., med Piranom in Izolo (CP I, št. 94).

19 SI PAK PI 9.1 Notarske pergamentne listine: 1283, 26. 1. (objav je več, mdr.: CP I, št. 168). 
Prvi piranski podestat je bil plemeniti mož, gospod Andreas Dandulo. Takoj po imenovanju si je zadal za nalogo, da naroči popis mejà piranskega komunalnega ozemlja. ${ }^{20}$ Soočil se je tudi s sporom Pirančanov in Izolanov in imenoval zastopnika, ki je zagovarjal piranske interese. ${ }^{21}$ Tudi sam beneški dož je s pomočjo članov različnih beneških svetov kasneje občasno imenoval razsodnike, ki jim je naložil, da popišejo mejo med Izolo in Piranom. ${ }^{22}$

Beneško obdobje je postreglo s prakso dokaj samostojnega medkomunalnega urejanja mejnih incidentov, v primerih konsenzualne nesposobnosti pa so bili v razsojanje - včasih po posredovanju “od zgoraj” - pritegnjeni tudi objektivni tuji arbitri. Razlog za medsosedske spore je bila pogosto košnja trave ali paša na ozemlju sosednje komune. Pirančani so se zaradi nje večkrat pravdali z Izolani in pred pričami dokazovali njihovo krivdo. ${ }^{23} \mathrm{Na}$ meji obeh komun je verjetno prihajalo tudi do medsebojnih fizičnih obračunavanj. Izolski veliki svet je zato avgusta 1320 sklenil prepovedati Izolanom, da bi zunaj območja Izole nosili orožje razen meča, noža in ščita. Nadzor naj bi opravljali piranski in izolski gozdni čuvaji. Morilca bi za večno izgnali, za prelivanje krvi in druge poškodbe pa je bila predpisana globa. Izolani niso smeli loviti na piranskem ozemlju, pač pa so smeli Pirančani slediti svojim psom, ki so gonili divjad s piranskega na izolsko območje. Divjačina, ki jo je pes ujel, je pripadla piranskemu lovcu. Tak dogovor s Piranom naj bi veljal pet let, njegove kršitve pa naj bi obravnavala beneška dož in komuna. ${ }^{24}$

Kadar se med seboj niso uspele dogovoriti, so sprte komune reševanje sporov predložile višjim instancam. Pirančani in Izolani so svoje teritorialne razprtije včasih reševali na ravni lastnih vrhovnih predstavnikov (podestatov), ki se jim je po potrebi pridružil tudi podestat in kapitan sosednjega Kopra. ${ }^{25}$ Oktobra 1285 je v spor med Piranom in Izolo posegel beneški dož in njegovo reševanje naložil trem zunanjim arbitrom: podestatom Kopra, Novigrada in Umaga. Za razsodnike, prijateljske pomirjevalce in urejevalce (arbitri, arbitratores et amicabili componitores, dispensatores) sta jih v imenu svojih mest potrdila

20 SI PAK PI 9.1 Notarske pergamentne listine: 1283, Piran (CP I, št. 176).

21 SI PAK PI 9.1 Notarske pergamentne listine: 1283, 3. 8., Piran (CP I, št. 172).

22 SI PAK PI 9.1 Notarske pergamentne listine: 1321, 29. 8., San Basso (CP II, št. 43).

23 SI PAK PI 9.1 Notarske pergamentne listine: 1283, 3. in 4. 8., med Piranom in Izolo (CP I, št. 173); $1283,6$. 8., Izola (CP I, št. 174); 1283, 6. 8., Izola; 1285, 13. 8., Piran; 1303, 24. 6., Piran (CP II, št. 9); 1303, 25. 6., Izola (CP II, št. 10).

24 SI PAK PI 9.1 Notarske pergamentne listine: 1320, 11. 8., Izola (CP II, št. 38).

25 SI PAK PI 9.1 Notarske pergamentne listine: 1315, 2. 8., Koper (CP II, št. 32); 1315, 2. 8., Koper (CP II, št. 33). 
tudi po dva predstavnika Izole in Pirana. ${ }^{26}$ Kot razsodniki-mediatorji so prihajale v poštev tudi ugledne cerkvene osebe, ki so v očeh obeh strank uživale sloves nepristranskosti. Tak je bil nedvomno tudi novigrajski škof Naticherus, ki so mu 1301 svoja nerešena mejna vprašanja zaupali piranski in bujski predstavniki. ${ }^{27} \mathrm{Na}$ njegovo določitev meje so se stranke pogosto sklicevale v primerih kasnejših kršitev "mejne črte”.

\section{Piransko ozemlje pod Benetkami}

Po predaji Pirana Benetkam je še v istem letu 1283 piranski podestat, plemeniti mož gospod Andreas Dandulo dal popisati piransko komunalno posest. ${ }^{28}$ Za izvedbo te naloge je imenoval sedem uglednih piranskih modrecev ( sapientes): gospoda Adalperija Elie, Henrica Taglacoça, Facina Vitala, Iohanesa Marana, Nicola Picha, Anoa de Apolonio in Adelgherija Vitala. Prisegli so k evangeliju, da bodo popisali in prisodili piranski komuni vso posest, za katero so vedeli, da ji pripada. Anoe se je od sklepa vzdržal.

Razsodniki so določili, da spadajo k piranski komuni posesti pod velikim potokom, ki je tekel prek srede Nožeda (Noxedum), in vinograd proti Nožedu do meje z Izolo. Od drugega konca Nožeda proti Padernu (Paternum) je meja tekla od zgornje strani od zgornjega konca vinograda Petra Otona, od zgoraj od konca vinograda Prohene, naravnost do spodnjega konca vinograda Bernarda pokojnega Fabe, od tam pa naravnost od konca vinograda sinov Almerica de Petrogna, nato naravnost in od spodnjega konca vinograda Carona, potem naravnost čez do potoka in do zgornjega konca vinograda sinov Almerica de Deuthomario, od spodnjega konca vinogradov sinov Flabiana in Çanuta, od koder je prečila naravnost čez od zgornjega konca vinograda, ki je pripadal pokojnemu Facini Çuchi in potem naravnost čez kot je tekla meja z Izolani in zgoraj od ozemlja Vuago. Na območju Liminjana (Limignanum) so določili razmejitev od spodnjega konca vinograda Iohannesa Mançolla, od spodaj od spodnjega konca vinograda Iohannesa Pine in Hotona Parussa in od spodnjega konca vinograda Munca Sena, od zgornjega konca vinograda Othonella Parusa, od tam od spodnjega konca vinograda Iohannesa de Fonda, od tam naravnost od konca vinograda vdove po Odoricu de Centumeço in naravnost prek od konca vinograda Facine Foie, nato je prečkala naravnost

\footnotetext{
26 SI PAK PI 9.1 Notarske pergamentne listine: 1285, 8. 10., Koper (CP I, št. 184); 1285, 19. 10., Koper (CP I, št. 185); 1285, 8. in 19. 10., Koper (kopija obeh prejšnjih dokumentov).

27 SI PAK PI 9.1 Notarske pergamentne listine: 1301, 18. 3., med Piranom in Bujami (CP II, št. 16).

28 Prim. op. 20.
} 
čez od zgornjega konca vinograda Sherii de Varnerio iz Lucana (Luçanum). Od zidu v Lucanu je meja šla navzdol po potoku (avarnus), ki je tekel navzdol $\mathrm{v}$ dolino Kavarije (Cavricis) in naravnost navzdol do izvira de Naxello. Vse čistine so pripadale piranski komuni. Od omenjenega izvira je meja sledila póti po dolini Karbonar (Carbonarium) do kostanjev na čistini de Rorullis, od tam navzgor do kostanjev v Rižente (Resente). Potem je prečkala naravnost čez do škarpe na čistini Rižente (Rexente). Vse posesti znotraj teh meja so pripadale piranski komuni. Od čistine Vsi Sveti (Omnes Sancti) so določili mejo od zidu ob koncu gozda v Karbonaru naravnost čez po potoku do javne poti v dolini Šentjane (Sanctianne), nad stezo čistine Vseh Svetih do spodnjega konca vinograda Valexija Pitidone, od zgornjega roba oljk Pelucija, sina pokojnega Volte, do treh velikih škarp neobdelanega zemljišča v Sv. Lovrencu (Sanctus Laurencius) nato naravnost čez po čistini do klanca de Urgnano, od zgornjega konca vinograda Rencholfa Çerbina, do neobdelanega zemljišča v Kavaljeru (Cavallirium). Od tam je meja prečkala od spodnjega konca vinograda Henrica de Iname, $v$ katerem je bila parcela mais, in naravnost od spodnjega konca vinograda Andriolla de Mathia, od tam od zgornjega konca vinograda Brisigne, v katerem je bila češnja, od tam naravnost do kolovoza, ki je vodil od Fažana (Faxanum) zgoraj do Lucana, naravnost čez okrog od spodnjega konca vinograda Francisca čez do potoka, do velike škarpe na zgornjem koncu vinograda Nicola Soldana, od tam pa naravnost prek od spodnjega konca vinograda Henrica Iudea itd.

Iz opisa je razviden nekdanji način določanja meja: ob mikrotoponimih, od katerih se mnogi niso ohranili do danes, se je posluževal mejà lastniških posesti, večkrat tudi priložnostnih znakov in oznak na terenu, kar onemogoča sledènje meji v sodobnem okolju.

\section{Meja Pirana in Buj pod patriarhi}

Najstarejši ohranjeni opis meje Pirana z Bujami in Kaštelom je ohranjen $\mathrm{v}$ že omenjenem dokumentu iz maja 1212, njegov pobudnik pa je bil - kot omenjeno - istrski in kranjski mejni grof, oglejski patriarh Wolfger. ${ }^{29} \mathrm{~V}$ prisotnosti konzulov ali gastaldov Pirana in Pirančanov ter bujskega gastalda in Bujčanov je izbral tri dobre in razsodne osebe: Dominica de la Figara iz Umaga, Petra de Valera iz Pirana in Papona de Vida iz Buj, da določijo meje posesti obeh komun. To so tudi storili.

29 Prim. op. 14. 
Popis meje navaja številne mikrotoponime, vendar se njihova imena na terenu niso ohranila do novejšega časa. Meja je tekla od izvira Antonia naravnost do jezera Pinçilinum, ki je ostalo na strani Kaštela, od tam do kmetije Dominica Rola, potem do poti Pelegrini Belegio med ozemljem Pirana in sv. Petra na savudrijskem Krasu (Sanctus Petrus de Carso). Od tam je potekala do kraja imenovanega Carnielo in potem naravnost do doline Castanei, nato do izvira de Lorno. Od tam se je nadaljevala do doline, ki se je imenovala Scunchigata, nato do hriba in dalje do brezna de la Figara, nato do doline de Campene, ki je pripadala Piranu. Potem je tekla do morske obale de Orçale in od tam do javne poti, nato do doline, ki se je imenovala Pradiçolo nasproti Piranu. Nadaljevala se je do zemljišča pokojnega gospoda Adelgerija de Cuniça. Pri dolini de Loçe je potekala do morskega brega, pri čemer je zemljišče gospoda Iohannesa Almerica skupaj z ribolovnim območjem (piscaria) v dolini ostalo Piranu. Ozemlje od meje proti Piranu naj bi bilo piransko. Predstavniki Pirana, Buj in Umaga so se z mejo strinjali in se jo zavezali spoštovati v imenu svojih komun pod kaznijo 1000 mark, od katerih bi polovica pripadla oškodovani strani, pol pa patriarhu. Enaka kazen bi v primeru nespoštovanja dogovora doletela patriarha.

\section{Reševanje mejnih vprašanj Pirana in Buj 1295/1296}

Sredi devetdesetih let 13. stoletja nedotakljivost meje ni bila več tako samoumevna. Nasprotje je verjetno izhajalo tudi iz dejstva, da je v Bujah, ki so šele $1412^{30}$ sprejele in priznale beneško nadoblast, imel tedaj prevladujoč vpliv patriarh, ${ }^{31} \mathrm{v}$ Piranu pa njegov konkurent in nasprotnik, beneški dož. Maja 1295 je pred piranskega podestata Marca Micaela prišel Bujčan Iohannes de Rosa, ki je bil sel in poslanec bujskega gastalda in Bujčanov. V imenu gastalda in bujske komune ter v prvi vrsti gospoda patriarha (!) je od Pirančanov zahteval, da zapustijo in vrnejo posesti na bujskem ozemlju, ki so jih nedavno zasedli. Piranski podestat je zatrdil, da ne ve in ne verjame, da bi Pirančani zasedli kako bujsko posest, in misli, da to ni res. Če pa bi se izkazalo, da obtožba drži, je pripravljen škodo dvakratno povrniti. Nasprotno pa je sam očital Bujčanom, da so oni zasedli ozemlje piranske komune. V imenu gos-

30 Istarska enciklopedija, Zagreb 2005, 116.

31 Buje, ki so prej priznavale nadoblast oglejskega patriarha, so 1268 prešle pod grofa Alberta Goriškega, ki je upravo nad njimi zaupal Kopru. V razdobju sedisvakance patriarhove stolice od 1268 do 1272 in v sledečem poldrugem desetletju so v zahodni Istri razširile svojo oblast Benetke, ki so tudi izničile ozemeljske apetite Alberta Goriškega po Istri. V sklepnem delu novega konflikta 1287-1290 med Benetkami in patriarhom, ki so se mu pridružili Trst in Koper ter goriški in koroški plemiči, je patriarh pridobil nazaj Milje, Kaštel, Buje in Dvigrad, ki so bili v času spopadov pod Benetkami (Ivetic [ur.], Istra kroz vrijeme, 219-221). 
poda doža (!), zase in za piransko komuno je zahteval od bujskega gastalda in komune, da zapustijo piransko ozemlje, ki so si ga pridržali. Da pa bi se vprašanje rešilo, je zaprosil bujskega gastalda, Bujčane in omenjenega poslanca, naj pošljejo svoje ljudi tja, kjer domnevajo, da so Pirančani zasedli njihove posesti, na njihovo željo pa bo tudi sam poslal na ogled svoje ljudi. Ti bodo za vsako stran pregledali, preiskali in glede omenjenega storili, kar je prav za dobrobit in slogo obeh strani. Če pa se ne bi mogli dogovoriti, bodo za vsako stran izbrali dobre stare deželane iz okoliša, ki bodo pregledali, določili in dodelili vsaki strani, kar ji gre. Zapis izpod peresa piranskega (!) notarja Dominichina omenja, da je piranski podestat s sodniki zase, za piranski svet in ljudi ter piransko skupnost to povedal prijateljsko in previdno kot tisti, ki si želijo in prizadevajo živeti z Bujčani v miru kot dobri sosedje in prijatelji.

Prijateljska pot dogovarjanja načelnikov mestnih komun ("premierski” dogovor) pa je v novembru obrodila sadove. ${ }^{32}$ Sešitek s popisom stroškov, ki sta jih za november in december 1295 ter za januar in februar 1296 poravnala Mengolinus Petrogne in Valesius Venerija, komornika (zakladnika) piranske komune v času častitljivega piranskega podestata plemenitega gospoda Nicolaja Dandulo, navaja seznam izdatkov, ki sta jih izplačala za potrebe mesta Piran. ${ }^{33} \mathrm{~V}$ seznamu sta skupka stroškov dveh masovnih pojedin na med- in nadmestni ravni. Do prve je prišlo ob srečanju piranskega in bujskega podestata, druga pa je spremljala trodnevni obhod meje med piransko in bujsko komuno, ki sta ga opravila piranski podestat in namestnik oglejskega patriarha za Istro (marchio).

Začnimo pri prvem dogodku. V nedeljo 13. novembra je bil piranski podestat (Nicolaus Dandulo) s sodniki in drugimi piranskimi modreci na pogovoru (coloquium) z gospodom Vicardom (iz Petrapilose), sicer bujskim podestatom, na dopoldanski zakuski (prandium) pri Sečovljah (apud Siçolas). Prisotnih je bilo približno sto in več oseb. Izdatki srečanja so znašali 24 soldov $^{34}$ in 4 denariče ter dodatnih 10 denaričev za kruh, 48 soldov in 4 denariče za dve urni ${ }^{35}$ in pol vina, 38 soldov za 76 liber $^{36}$ govejega mesa, 39 soldov in 2

32 Darja Mihelič, "Reprezentančni stroški srednjeveških mestnih mogôtcev (Piran, zadnje desetletje 13. stoletja)", v: Marija Mogorović Crljenko - Elena Uljančić-Vekić (ur.), Cerealia, oleum, vinum ---, Kultura prehrane i blagovanja na Jadranskom prostoru / Dining culture in the Adriatic Area, Pazin-Pula-Poreč 2009. (3. Istarski povijesni biennale, 3), 55-62.

33 CP I, št. 221.

34 Tedaj veljavna denarna razmerja so bila: 1 libra $=20$ soldov $=240$ denaričev; 1 sold $=12$ denaričev.

351 urna = 64,7 litra, prim. Darja Mihelič, "K osvetlitvi nekaterih votlih mer srednjeveškega Pirana”, Kronika, $37,1989,22-26$.

$36 \quad 1$ libra $=0,477$ kilograma. 
denariča za 47 liber svinine, 1 grošs ${ }^{37}$ za sveče in za natovarjanje in raztovarjanje plovil, 6 soldov za Dionisija, ki je nesel pismo piranskega podestata bujskemu podestatu gospodu Vicardu, 29 soldov za začimbe, izposojo skodelic, vrčev za vino in krožnikov in za poškodbe na posodah, ki so se na poti razbile, ter 7 soldov za sedem jerebic.

Iz naštetih podatkov moremo sklepati, da se je omenjenega dne piranski podestat sešel z bujskim na pogovoru ob dopoldanski zakuski pri Sečovljah, pojedini pa so prisostvovali številni izbranci. Gostitelj - piranski podestat je h gostu iz Buj najprej poslal sla Dionisija z vabilom. Bujski podestat se je vabilu očitno odzval. Pirančani so na plovilih dostavili v Sečovlje hrano, pijačo, začimbe in posodje. Prek sto udeležencev dogodka je pojedlo kakih 65 kilogramov mesa (dobrih 36 kilogramov govedine, dobrih 22 kilogramov svinine in 7 jerebic), približno 75 enot kruha (količina enot je izračunana po podatkih drugega stroškovnika, velikost enote pa ni ugotovljiva) ter popili nekaj nad 160 litrov vina. H kilogramu mesa so pojedli nekaj več kot enoto kruha in jo poplaknili s skoraj poltretjim litrom vina. Posamezen udeleženec pojedine je v povprečju použil dobrega pol kilograma govejega, svinjskega ali jerebičjega mesa, zraven prigrizoval kruh (skoraj tričetrt enote) ter popil dober liter in pol vina. Stroški hrane in pijače na osebo so znašali skoraj 18 denaričev oz. poldrugi sold, kar je bilo enakovredno ceni petih litrov vina iz tega stroškovnika.

Vino so natakali iz trebušastih vrčev. Pili so iz skodelic, jedli pa s krožnikov. Dopoldanska zakuska se je zavlekla še v noč in se nadaljevala ob razsvetljavi sveč, ki se tudi omenjajo med stroški. Izdatki za sestanek na medmestni ravni so bili enakovredni ceni več kot 6 in pol hektolitra vina, diplomatski uspeh pogovora pa je bil ugoden, kar moremo sklepati iz nadaljnjih podatkov stroškovnika.

Piranski podestat si je decembra istega leta skupaj z namestnikom patriarha za Istro Musco della Torre tri dni ogledoval mejo med piransko in bujsko komuno. Zapis navaja k datumu januarskih kalend (1. januarja, že po dogodku) naslednje izdatke: 3 libre in 1 in pol solda za 125 liber govedine, ko je bil gospod piranski podestat z gospodom Musco de la Turre, namestnikom patriarha za Istro, ob meji Buj, da bi si ogledal razmejitev s Piranom, potem 52 soldov za svinino za to pot, dalje 33 soldov in 4 denariče za 100 enot kruha, 18 grošev za tri urne vina, 35 soldov za začimbe in izposojo skodelic, vrčev za

371 groš $=32$ denaričev. 
vino in krožnikov in za poškodbe na njih, 10 in pol groša za jerebice, 6 soldov in 2 denariča za natovarjanje plovila ob odhodu in vrnitvi v Sečovlje (Siçolle), 18 grošev za najem treh konj iz Kopra za tri dni, potem 6 soldov za konjarja, ki je konje pripeljal iz Kopra in jih odpeljal nazaj, 24 soldov za tri stariče ječmena za konje ter 20 denaričev za podkev in žeblje.

Poizkusimo razložiti naštete podatke. Zdi se, da je bil ogled meje plod novembrskega dogovora veljakov iz Pirana in Buj. Ogledniki so se odpravili na pot iz Sečovelj, ki so bile začetna, morda pa tudi končna postaja njihove poti. Tja so si dali s plovilom dostaviti vse potrebno za potovanje. Mejo med piranskim in bujskim območjem so ogledniki objezdili. Primerne konje za ježo je pripeljal iz Kopra poseben konjevodec. Eden izmed konj je spotoma izgubil podkev in ga je bilo treba podkovati. Konje so krmili z ječmenom. Posamezen konj je dnevno pojedel dobro petino stariča (neznane velikosti) ječmena. Človeški udeleženci so na poti pojedli približno 110 kilogramov mesa (skoraj 60 kilogramov govedine, 30 kilogramov svinine in 21 jerebic), 100 enot kruha in popili slaba dva hektolitra vina. Na dan so konsumirali čez 35 kilogramov mesa (skoraj 20 kilogramov govedine, 10 kilogramov svinine in 7 jerebic), čez 30 enot kruha in popili približno 65 litrov vina. H kilogramu mesa so pojedli malo manj kot enoto kruha in popili skoraj dva litra vina. Število udeležencev pohoda ni znano, so pa k mesu pojedli manj kruha in popili več vina kot pri zakuski v Sečovljah. Skupni stroški trodnevnega ogleda meje so bili enakovredni ceni slabih 14 hektolitrov vina iz tega stroškovnika, povprečni dnevni stroški pa ceni nekaj več kot štirih hektolitrov in pol vina.

$\mathrm{V}$ istem mesecu januarju zasledimo še strošek 28 soldov za sedem ljudi, ki so šli določit mejo med piransko in bujsko komuno; vsak je dobil 7 soldov. Diplomatska akcija je bila tako zaključena, sicer pa je podatkov o stroških v zvezi s stiki z Bujami v zapisu še več.

\section{Razmejitev piranskega in bujskega ozemlja 1301}

Razsojanje o razmejitvi piranskega in bujskega ozemlja, ki ga je 18. marca 1301 na mejnem ozemlju med Piranom in Bujami (in confinibus Pirani et de Bullis) kot razsodnik-mediator obeh strani opravil novigrajski škof Naticherus, ${ }^{38}$ smo okvirno že omenili. Prisotne naprošene priče so bili cerkveni dostojanstveniki iz Novigrada in Buj in ugledni bujski in piranski laiki: novigrajski arhidiakon gospod Dionisius, diakon Simonus, novigrajski kanonik, duhovnik

38 Prim. op. 27. 
Mengosius iz Buj, Bujčani Besponus pokojnega Basiana, Beachinus, Bertaldus in Petrus Peverellus iz Buj, ter piranski gospodje Apolonius de Apolonio, Nicola Picha, Almericus de Petrogna in Anoe de Polonio. Piranski podestat Matheus Manolessus se je devet dni prej, 9. marca, skupaj s svojimi štirimi sodniki in velikim svetom $v$ imenu piranske skupnosti zaobljubil in dal polna pooblastila novigrajskemu nadškofu (ta naj bi bil arbiter, arbitrator et amichabilis compositor), da razsodi o piranskih vprašanjih, nasprotjih in sporih z Bujami; omenjeni so se zavezali zase in za naslednike v imenu piranske skupnosti spoštovati škofovo odločitev. Bujski velikaši pa so v imenu malega in velikega sveta na podoben način že 25. februarja v isti zadevi pooblastili novigrajskega škofa (kot judicem, arbitratorem et amichabilem compositorem) na njegovo lastno pobudo, ko se je želel v celoti seznaniti z vprašanji med Piranom in Bujami. V obeh pooblastilih je bila predvidena globa za kršitev 100 mark ${ }^{39}$ pri čemer je bujski dokument predvidel, da polovica globe pripade novigrajskemu škofu, polovica pa prizadeti strani, ki bi razmejitev spoštovala.

Opisana razmejitev danes na terenu ni določljiva, saj se njen potek sklicuje skoraj izključno na s križi in žeblji označene naravne objekte, drevesa in skale, ki so imeli vlogo mejnikov. Opis meje proti Umagu začenja z jamo, v kateri je rasla figa, in se nadaljuje proti vzhodu do hrasta, označenega s križem in žeblji, mimo naslednjega hrasta s križem, do enako označene skale, dalje do enako zaznamovanega hrasta na koncu doline, pa do na enak način označenega hrasta ob nekem dvorišču, potem zapored še do dveh enako zaznamovanih hrastov, naravnost prek do s križem in žeblji označenega velikega cera, blizu katerega je ležala s križem zaznamovana skala, nato do naslednjega enako označenega hrasta, potem naravnost do hrasta zaznamovanega z dvema križema na koncu doline, nato do dveh drugih na enak način označenih hrastov na vzpetini de Spinosa, potem do velikega hrasta pri vodnjaku de Spinosa, zaznamovanem z dvema križema in žeblji, potem do omenjenega vodnjaka, na skali katerega sta bila na obeh straneh dva križa. Vodnjak naj bi bil na razpolago obema komunama, Piranu in Bujam. Meja se je po opisu nadaljevala do naslednjega hrasta $z$ dvema križema in nato proti vzhodu do s križem označene skale, pa naprej do cera, na katerem so bili znak dveh križev in žeblji, nato do skale s križem, pa do velike skale, ki je bila podobna skrinji, na kateri je bil križ, potem do enako označenega hrasta s križem in naprej do enako zaznamovane skale in do skale s križem poleg nje, potem naravnost do 
hrasta, označenega z dvema križema in žeblji, pa dalje do hruške, zaznamovane s križem, nato proti vzpetini poleg te hruške do hrasta, na katerem je bil znak križa in naravnost čez do drugega hrasta, označenega na enak način, potem zapored še do dveh hrastov s križem in končno naravnost do hrasta, ki je bil na meji obeh komun, Pirana in Buj in je bil zaznamovan s križem. Ozemlje proti Sečovljam je bilo prisojeno Piranu, tisto proti bujskemu castru pa Bujam. Samó omenjeni vodnjak naj bi bil skupen. Presoja škode na obeh straneh naj bi bila v pristojnosti beneškega doža in oglejskega patriarha. Kazen za kršitelja dogovora je znašala 100 mark. Dokument o razmejitvi naj bi se izdelal v treh izvodih, od katerih bi enega dobila piranska, drugega bujska komuna, tretjega pa novigrajski škof. Pirančani in Bujčani naj bi vsaka tri leta skupaj obnovili omenjene naravne označene mejnike.

\section{Incidenti in konflikti na piransko-bujski meji 1306}

Kljub natančni opredelitvi meje ali prav zaradi nje - vsak poseg nasprotne strani prek meje je bil zlahka razpoznaven - je kasneje prihajalo do kršitev. $\mathrm{V}$ takih primerih sta se obe strani - Pirančani in Bujčani - sklicevali prav na razmejitev novigrajskega škofa iz 1301. Pet let po njej je 2. februarja 1306 častitljivi piranski podestat plemeniti vitez (nobilis miles) gospod Badoarius Badoario skupaj s štirimi sodniki in zbranimi člani velikega sveta piranske komune v občinski palači imenoval razsodnega moža Dominica de Çaneto iz Pirana za poslanca, predstavnika in zastopnika (nuncium, sindicum et procuratorem), da bi od rektorjev, sveta, komune, ljudi in celotne skupnosti Buje zahteval, da spoštujejo razsodbo novigrajskega škofa o razmejitvi ozemlja med Bujčani in Pirančani. V imenu piranske komune, podestata, sveta in Pirančanov naj bi izrazil pripravljenost, da bo pazil in spoštoval vse postavke škofove razsodbe. Naznanil in ugovarjal naj bi za škodo, krivico in stroške, obresti in globo, če bujska komuna in Bujčani razsodbe ne bi spoštovali. ${ }^{40}$

Čez dvanajst dni, 14. februarja, je piranski zastopnik Dominicus de Çaneto v Bujah prosil in zahteval od Pellegrina, namestnika (vicarius) bujskega podestata nobili viri domini Vicardi de Petrapellosa, in od Biachina, načelnika (maricus) bujske komune, da naj čez osem dni ob tretji uri prideta na piransko-bujsko mejo zaradi obnove mejnikov in uresničitve določil razsodbe novigrajskega škofa iz 1301. Izrazil je pripravljenost, da tudi sam pride ob dogovorjenem času tja v imenu piranske komune, da bi izpolnil obveznosti

40 SI PAK PI 9.1 Notarske pergamentne listine: 1306, 2. 2., Piran (CP II, št. 16). 
iz razsodbe. V tem smislu se je na oba omenjena Bujčana obrnil tudi piranski poslanec (ambaxator) gospod Anoe de Appollonio. ${ }^{41}$ Slaba dva tedna kasneje, 27. februarja, so se na meji med Bujami in Piranom v prisotnosti treh prebivalcev Umaga zbrali častitljivi piranski podestat nobilis vir dominus Badoarius Badoario in predstavnik in zastopnik Pirana Dominicus de Çaneto, ki sta se jima za piransko stran pridružila piranska sodnika Valexe de Venerio in Caroti de Vitali, medtem ko je bujska stran za svoje predstavnike izbrala gospode Odorica, Fuscola, Petra Çacharie in bujskega klicarja (preco) Cristoforja. Poskrbeli naj bi za obnovo mejnikov med piranskim in bujskim ozemljem, ker je v nasprotju z razsodbo iz 1301 nekdo od Bujčanov na piranski strani oral in sejal žito blizu zadnjega s križem označenega hrasta-mejnika, Bujčani pa so nekaj hrastov tudi posekali. Piranski predstavnik in zastopnik se je pritožil bujskim poslancem in zahteval plačilo predpisane globe za kršitev. Bujčani so sprva trdili, da ne vedo, kdo je oral ali sejal na tisti zemlji, potem pa so povedali, da je bil to nekdo, ki se imenuje Petro Cunchiga. ${ }^{42}$

Ugotovitev ogleda glede spoštovanja piransko-bujske meje je razvidna iz dokumenta, datiranega s 6. marcem. V njem je zapisano, da so ljudje iz Buj na območju savudrijskega Krasa (Carsum) orali in sejali žito na ozemlju piranske komune blizu velikega hrasta, označenega s križem na meji med Piranom in Bujami. Piranski zastopnik Dominicus de Çaneto se je zato pritožil. Omenjenega dne sta se v piranski komunalni palači pred pričami Foscolus in Petrus Çacharie iz Buj, ki sta se z listino izkazala za poslanca bujskega namestnika, načelnika in sveta, $v$ korist piranskega podestata in piranske komune odrekla zorani zemlji in njenemu pridelku na piranski strani meje, ki jo je 1301 določil novigrajski škof Naticherius. ${ }^{43}$ Aprila je piranski zastopnik Dominicus de Çaneto pod velikim nadzidkom pred bujskimi mestnimi vrati zahteval od bujskega gastalda Cristoforja in načelnika Biachina, naj spoštujeta razsodbo novigrajskega škofa o meji ali pa plačata za kršilca predvideno globo, sicer se bodo piranski podestat in Pirančani obrnili na beneškega glavarja Istre capetanea paysanatici, ${ }^{44}$ da bi pomagal Pirančanom in jih podprl s svojo pra-

41 SI PAK PI 9.1 Notarske pergamentne listine 1306, 14. 2., Buje.

42 SI PAK PI 9.1 Notarske pergamentne listine 1306, 27. 2., med Bujami in Piranom.

43 SI PAK PI 9.1 Notarske pergamentne listine 1306, 6. 3., Piran (CP II, št. 17).

44 Po ustanovitvi tega urada 1301 je sprva imel sedež v Poreču, nato v Sv. Lovreču Pazenatičkem (od tod je ta sedež tudi dobil vzdevek "Pazenatički”). Skrbel naj bi za obrambo dežele, imel pa je tudi sodne pristojnosti. Prim. Sergij Vilfan, Zgodovinska pravotvornost in Slovenci, Ljubljana 1996. (Pravna obzorja, 5), 286-287; Darko Darovec, Kratka zgodovina Istre, Koper 2008, 74-76; Štih, Goriški grofje ter njihovi ministeriali in militi v Istri in na Kranjskem, 97; Marko Kostrenčić (ur.), Lexicon latinitatis medii aevi Iugoslaviae / Rječnik srednjovjekovnog latiniteta Jugoslavije, II, Zagreb 1978, 794. 
vico. ${ }^{45}$ 1. maja je Fuscolus iz Buj v piranski komunalni palači pred pričami želel ugovarjati piranskemu podestatu glede mejnih vprašanj med Bujčani in Pirančani. Piranski podestat pa mu ni priznal vloge zastopnika in predstavnika Buj, češ da o tem nima ustreznega dokumenta. Za bujsko komuno in Bujčane pa je Fusculu naročil, naj v osmih dneh izročijo človeka, ki je oral in sejal žito na savudrijskem Krasu na piranskem ozemlju ob zadnjem hrastu na meji med Piranom in Bujami ali pa naj plačajo globo. Fuscu samemu je dal osem dni časa za razmislek, kaj bo povedal glede piranskega ozemlja poleg jezera Pinçellinum, kjer je oral in sejal rž. ${ }^{46}$ 23. maja je pred piranskega podestata prišel poslanec bujske komune Leonardus, ki je med drugim izjavil, da ne ve, kdo je oral in sejal žito na Piranskem poleg zadnjega s križem zaznamovanega hrasta med mejnima ozemljema Buj in Pirana. Piranski podestat pa je - prepričan, da Bujčani dobro vedo, kdo je na tistem ozemlju oral in sejal - v imenu piranske komune prek Leonarda zahteval, naj mu bujska komuna izroči krivca ali kršilca, ki je na Piranskem oral in sejal ali pa naj plačajo globo. ${ }^{47} 25 .{ }^{48}$ maja je piranski podestat v imenu piranske komune naznanil in se pritožil Odorlicu iz Milj, zastopniku in predstavniku bujske komune in Bujčanov, imenovanem 25. (!) maja 1306, da naj mu Bujčani bodisi izročijo krivca, ki je oral in sejal na Piranskem pri zadnjem hrastu na meji med Piranom in Bujami ali pa naj plačajo predpisano denarno kazen. ${ }^{49}$

$\mathrm{V}$ začetku junija sta in situ ob že večkrat omenjenem hrastu-mejniku v prisotnosti eminentnih razsodnikov, novigrajskega škofa Naticherija, gospoda Anthonija iz Padove, sodelavca plemenitega moža, častitljivega beneškega istrskega glavarja (capitanei paysenatici Ystrie), ${ }^{50}$ gospoda Iohannesa Quirina, gospoda Marina Bemba, podestata Svetega Lovreča (Pazenatičkega), gospoda Angela Badoario, novigrajskega podestata, Petra Bellegno iz Benetk, gospoda Marina Ardiçoneja imenovanega Latro in drugih, uradna bujska predstavnika $\mathrm{v}$ roke plemenitega viteza, gospoda Badoarija Badoario za piransko komuno izročila žito, ki so ga Bujčani, predvsem Petrus Cunchiga, posejali na piran-

\footnotetext{
45 SI PAK PI 9.1 Notarske pergamentne listine: 1306, 25. 4., Buje (CP II, št. 18).

46 SI PAK PI 9.1 Notarske pergamentne listine: 1306, 1. 5., Piran (CP II, št. 19).

47 SI PAK PI 9.1 Notarske pergamentne listine: 1306, 23. 5., Piran (CP II, št. 21).

48 Listina je datirana na bolonjski način s 7. majem 1306 (die septimo intrante maio), vključuje pa zapis, $\mathrm{s}$ katerim se je Odorlicus iz Milj izkazoval za bujskega predstavnika, datiran s 25. majem (die septimo exeunte madio) istega leta. Listina se torej sklicuje na zapis, ki je nastal kasneje kot ona sama. Logično sosledje dogodkov vodi do sklepa, da je datacija listine napačna. Notar je verjetno namesto exeunte zapisal intrante ma(d)io, pravi datum listine pa je 25. maj.

49 SI PAK PI 9.1 Notarske pergamentne listine: 1306, 7. (dejansko 25., glej zgoraj) 5., Piran (CP II, št. 20).

50 Ta funkcija le bila stara le nekaj let (prim. op. 44), pa je njen nosilec že sodeloval pri urejanju mejnih vprašanj.
} 
skih tleh ob zadnjem hrastu-mejniku, in tudi rž, ki jo je na piranskem ozemlju poleg jezera Pinçellinum posejal Fuscus iz Buj, češ da stvari in žito, posejano na Piranskem, pripadajo Piranu. ${ }^{51}$

Le malo zatem je v spor tudi osebno posegel gospod Iohannes Quirino, po ukazu beneškega doža, slavnega gospoda Petra Gradonico Paysanatici $\Upsilon$ strie capitaneus generalis, arbiter et arbitrator et amicabilis compositor za vprašanje med piransko in bujsko komuno, kot je razvidno iz dveh zapisov enake vsebine o dogovoru z obeh strani. Dokument, zapisan 12. junija v loži poreške škofije nad morjem, kjer se je tedaj mudil omenjeni razsodnik, se sklicuje na zapis iz 4. junija. Ugotavlja potek spora med piransko in bujsko komuno, ki se je začel s tem, da so piranski podestat in Pirančani trdili, da so Bujčani sekali in dali sekati drevesa in druga mejna znamenja na meji obeh komun, ki jo je določil častitljivi oče novigrajski škof Naticherius, in da so pulili žeblje iz mejnikov ter sejali žito na ozemlju piranske komune poleg hrasta-mejnika, označenega s križem. Bujska komuna in Bujčani so to zanikali. Zastopniki in predstavniki, ki sta jim komuni podelili polnomočje, so kot sodnika, razsodnika, prijateljskega pomirjevalca in urejevalca (arbitrum, arbitratorem, amicabilem compositorem, dispensatorem) in dobrega moža skupno in složno določili plemenitega in modrega moža gospoda Iohannesa Quirino, častitljivega gla-

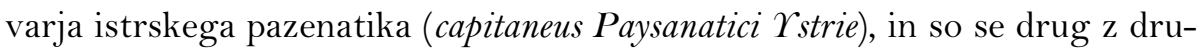
gim v imenu obeh komun slovesno pogodili, da bodo ubogali razsodnika in ne bodo ugovarjali njegovi razsodbi. Globa za kršitev bi znašala 100 mark. Omenjeni razsodnik je določil, naj vse žito, ki so ga Bujčani posejali tako na piranskem kot na bujskem ozemlju, glede katerega je tekel spor, pripade piranski komuni in Pirančanom. Glede drugega zahtevka o ureditvi meje in mejnikov obeh ozemelj pa naj bi šli tja in oznake popravili v petnajstih dneh pod kaznijo 50 mark. ${ }^{52}$ Pirančani so že 16. junija ukrepali v skladu z omenjeno odločbo: piranski poslanec gospod Appollonius pokojnega Appollonija iz Pirana je pred vrati bujskega castra zahteval od Biachina, načelnika bujske komune kot zastopnika Buj, naj njegova komuna in Bujčani pod kaznijo 50 mark na lastne stroške $\mathrm{v}$ petnajstih dneh $\mathrm{z}$ jarki, stebri ali kamni popravijo mejne oznake med piranskim in bujskim ozemljem v skladu $\mathrm{z}$ razsodbo istrskega glavarja gospoda Iohannesa Quirina. Bujčani so zagotovili, da bodo

51 SI PAK PI 9.1 Notarske pergamentne listine: 1306, 4. 6., savudrijski Kras (CP II, št. 22).

52 SI PAK PI 9.1 Notarske pergamentne listine: 1306, 12. 6., Poreč (CP II, št. 23). 
na meji, ki je potrebna popravka naslednji ponedeljek ${ }^{53}$ zjutraj. ${ }^{54}$ Zagotovila pa se niso držali. Na dogovorjeni dan snidenja 20. junija je zato na savudrijskem Krasu v prisotnosti prič iz Pirana in Buj notar Sclavonus de Billono kot zastopnik in predstavnik piranskega podestata plemenitega viteza gospoda Badoarija Badoario, piranskega sveta, komune in ljudi naznanil in se pritožil bujskemu zastopniku Biachinu iz Buj, ker bujska komuna ni spoštovala razsodbe glavarja Iohannesa Quirina in ni dala popraviti mejnikov med komunama s stebri iz malte in ni storila ostalega, kar je določala omenjena razsodba. Zahteval je, da bujska komuna in Bujčani plačajo v razsodbi predvideno globo 50 mark. ${ }^{55}$

Da pa tudi Pirančani v odnosu do Buj niso bili nedolžna jagnjeta, je razvidno iz poldrugo desetletje kasnejšega zapisa. Avgusta 1320 je v Piranu $\mathrm{v}$ prisotnosti koprskega notarja Bertaldina, umaškega prebivalca Iohannesa Coppa iz Benetk, umaškega župnika prezbitra Odorika in drugih prič Cittadinus pokojnega Biachina iz Buj izjavil pred častitljivim piranskim podestatom gospodom Nicolaom Savonario, omenjenimi pričami in notarjem Petrom iz Benetk, da je od piranskega komornika Sclavona Biloni prejel 49 liber in 12 denaričev. Ta denar je na podestatov ukaz izročil komorniku Henricus Iohannesa Çagneta iz Pirana zaradi spora med piransko in bujsko komuno glede ozemlja Sv. Petra na savudrijskem Krasu (de Carso). ${ }^{56}$

\section{Sklep}

Spoznanja, ki jih nudijo omenjeni primeri določanja mejà podrobneje osvetljujejo vsebino in prostor srednjeveških istrskih mestnih naselbin, ki niso bile omejene le na urbano ali utrjeno jedro, ampak so vključevale in obvladovale širši agrarni okoliš. V tem okviru so - kljub nadrejeni oblasti v Istri - razvijale lastno upravo in sodstvo in predstavljale teritorialno zaokrožene mestne državice, ki so v urbanem okolju severozahodne Istre mejile druga na drugo. Svoje ozemlje in meje so skrbno varovale. Raznolike kršitve mejà s strani sosednjih komun so vodile v medsosedske spore, ki so jih vpletene strani reševale na različne načine: s premišljenim dogovarjanjem ali s pomočjo nadreje-

\footnotetext{
53 Ponedeljek po 16. juniju 1306 je bil 20. junija.

54 SI PAK PI 9.1 Notarske pergamentne listine: 1306, 16. 6., Buje (CP II, št. 24).

55 SI PAK PI 9.1 Notarske pergamentne listine: 1306, 20. 6., savudrijski Kras (CP II, št. 25).

56 SI PAK PI 9.1 Notarske pergamentne listine: 1320, 5. 8., Piran (CP II, št. 37).
} 
nih istrskih oblastnikov ${ }^{57}$ ter drugih svetnih in cerkvenih veljakov.

Način določanja mejà v času, ki ni poznal podrobne kartografije in katastrskih izmer, se je naslanjal predvsem na geografske ločníce in terenske značilnosti: na potoke, izvire, gozdove, jame, prepade, (označene) skale, škarpe, (označena) drevesa, kolovoze, potí, lastniške parcele, (označene) vodnjake itd. Nekatere razmejitve omenjajo več ledinskih imen, v drugih teh skoraj ne zasledimo in se opirajo le na značilnosti terena, nekatere pa vzpostavljajo razmejitev s pomočjo označenih mejnikov. To so bili s križi in žeblji označena drevesa in skale, ki so se nahajali dokaj blizu drug drugemu.

Oblike kršitev in razlogov za spore med mestnimi komunami glede njihovega ozemlja povzemamo po določilih piranskega statuta iz $1307 .{ }^{58}$ Spore je najpogosteje sprožilo odtujevanje trave ali sena, paša ali obdelava in izkoriščanje tujih tal. Po dogovoru s Piranom iz 1320 Izolani niso smeli loviti na Piranskem, pač pa so smeli piranski lovci slediti svojim psom, ki so gonili divjad s piranskega na izolsko ozemlje. Če je pes tam divjačino ujel, je pripadla piranskemu lovcu. ${ }^{59}$

Osebe, ki so bodisi ob nastopu funkcije ali v primerih medkomunalnih sporov posegale v reševanje mejnih vprašanj, so bile različne. Le nekaj let za tem, ko je prejel mejno grofijo Istro (1209), je 1212 oglejski patriarh Wolfger dal popisati mejo med Piranom in Izolo, še v istem mesecu tudi med Piranom in Bujami. Leta 1254 je njegovemu zgledu poseganja v razmejitev Pirana in Izole sledil tudi patriarh Gregor de Montelongo. Wolfger je v prisotnosti gastaldov in konzulov Pirana, Kopra in Izole za določanje meje med Piranom in Izolo izbral pet dobrih in razsodnih mož: dva Tržačana in tri Umažane, za določanje piransko-bujske meje pa v prisotnosti konzulov ali gastaldov Pirana in bujskega gastalda tri dobre in razsodne moške: po enega iz Umaga, Pirana in Buj. Patriarh Gregor je opravilo piransko-izolskega razmejevanja

57 Istra, ki je bila od 952 del Svetega rimskega cesarstva, je po sredi 11. stoletja pridobila status mejne grofije. Naslov in oblast mejnih grofov je bila ob krajšem intermezzu oglejskih patriarhov (1077-1078) v rokah različnih plemiških družin (Weimar, Eppenstein, Spanheim, Andechs). Leta 1208 je pripadla bavarskemu vojvodi Ludviku, leto kasneje pa oglejskemu patriarhatu, kjer je stoloval patriarh Wolfger. Ta je tedaj pridobil oblast nad obalnimi zahodnoistrskimi mestnimi naselbinami. Te so od 12. stoletja izgrajevale komunalno avtonomijo in gojile živahne stike z zahodno obalo Jadrana, zlasti z Benetkami, ki so že od prve polovice 10. stoletja dalje vzpostavile in postopno krepile stike $\mathrm{z}$ njimi. Težnje po razširitvi oblastí v tem prostoru so v 13. stoletju privedle Benetke v konflikt s patriarhi, katerih oblast v Istri je v drugi polovici 13. stoletja slabela. Benetke, ki jim je načeloval dož, so v zadnjih desetletjih 13. stoletja razširile oblast nad številnimi istrskimi mesti. Pustile so jim avtonomijo, za podestata pa so jim imenovale svojega človeka. Dogovor med Benetkami in patriarhatom 1307 je iz oglejske mejne grofije tudi formalno izločil Koper, Piran, Novigrad, Poreč, Rovinj in Motovun, medtem ko sta bila Umag in Izola že pred tem beneška (Ivetic [ur.], Istra kroz vrijeme, 221-222.). Benetke so $1301 \mathrm{v}$ Istri uvedle tudi funkcijo istrskega deželnega glavarja $\mathrm{z}$ vojaškimi in sodnimi pristojnostmi. Mesta pod beneško oblastjo so mu bila podrejena v vojaškem pogledu.

58 Prim. op. 11.

59 Prim. op. 24. 
zaupal podestatu tedaj zelo vplivnega mesta Koper, ki je pridobil pooblastila koprske in piranske podestarije in patriarhovega namestništva v Istri, nato pa določil mejo s pomočjo koprskih modrecev.

Komunalna avtonomija je v tem času že dosegla tolikšno zrelost, da sta se sprti strani za rešitev mejnega spora znali sporazumeti tudi brez posrednikov “od zgoraj”. Sredi petdesetih let 13. stoletja sta se piranska in izolska komuna obrnili na zaupanja vrednega razsodnika in mediatorja: to vlogo sta zaupali koprskemu podestatu.

Po uradni uveljavitvi beneške oblasti v obalnih istrskih mestih so vprašanja mejà reševali mestni glavarji podestati, ki so jih postavljale Benetke. Prvi piranski podestat Andreas Dandulo je popis meje piranske posesti zaupal sedmim uglednim piranskim modrecem.

Na območju beneške Istre je v primerih kršitev posesti s strani sosednjega mesta podestat imenoval uglednega meščana za zastopnika, ki se je v njegovem in v imenu svoje komune pritožil pred podestatom in sodniki sosednje komune, s pričami dokazal svojo obtožbo in dosegel priznanje krivde s strani kršilca. V bolj zapletenih primerih sta obe sprti komuni za reševanje spora pooblastili vsaka svojega zastopnika, kot razsojevalca pa sta nastopala podestata obeh komun, ki sta $\mathrm{v}$ razsojanje lahko pritegnila ugledno tretjo osebo; v primeru piransko-izolskega spora 1315 je bil to koprski podestat.

Bolj zapleteno je bilo iskanje ozemeljskih razsodnikov v Piranu in Bujah, ki sta sodila v območji različnih oblastnikov, Benetk (Piran) in oglejskega patriarha (Buje). Tudi v teh primerih je oškodovana komuna najprej poslala svojega poslanca s pritožbo k sosednjemu mestnemu glavarju (v Piranu je bil to podestat, $\mathrm{v}$ Bujah gastald).

Razsodnik-mediator, ki je užival zaupanje in prejel pooblastila obeh strani, je bil 1301 novigrajski škof Naticherius. Na njegovo razmejitev med Piranom in Bujami so se še kasneje sklicevali v primerih ozemeljskih sporov. Kot priče se v zapisu omenjajo cerkveni dostojanstveniki iz Novigrada ter ugledni gospodje iz Pirana in Buj. Pet let kasneje je prišlo do obsežno dokumentiranega spora zaradi kršitve piransko-bujske razmejitve s strani Bujčanov. Pirančani so pooblastili zastopnika, ki se je v Bujah pritožil, potem pa sta obe stráni poslali na mejo po štiri častitljive osebe, ki so se jim kot priče pridružili še trije nepristranski prebivalci Umaga. Poskrbeli naj bi za obnovo medkomunalnih mejnikov, ki so jih Bujčani uničevali. Zastopnik Buj je bil prebivalec Milj. Končno poravnavo glede meje so rešili na vrhunski ravni. 
V prisotnosti novigrajskega škofa, sodelavca beneškega istrskega glavarja paysenatici, podestatov Sv. Lovreča (Pazenatičkega), Novigrada, ugledneža iz Benetk ter še gospoda neznanega porekla, sta bujska predstavnika piranskemu podestatu izročila žito, ki so ga Bujčani pridelali na piranskem ozemlju. - Sicer je videti, da izbrani razsodniki niso mogli biti po godu Bujam: vsi so namreč prihajali iz beneškega "tabora”, medtem ko so bile Buje pod oblastjo patriarha. Buje pa so "beneške" razsodnike sprejele brez (znanih) ugovorov. To lahko razumemo kot razmerje moči med konkurentoma (patriarh - Benetke), v katerem se je razmerje sil prevešalo v korist slednjih. Po drugi strani pa je praksa razsodništva v srednjem veku potekala tako, da je šibkejša stran v sporu, ki si je želela poravnave in si prizadevala za prekinitev konflikta, praviloma izbirala posrednike med osebjem nasprotne strani. V vsakem primeru pa so bili posredniki vplivne, zaupanja vredne osebe, ki so uživale nesporno avtoriteto. ${ }^{60}$

Malo kasneje je istrski glavar obnovil zahtevo, naj Bujčani v roku petnajstih dni uredijo meje in mejnike, do česar pa ni prišlo. Kršitve s strani Pirančanov so skromneje dokumentirane, kar pa ne pomeni, da jih ni bilo.

Primerjava s sodobnimi razmerami kaže, da so se v primeru manjših sporov na medmestni ravni pogajali mestni zastopniki in modri izvedenci, ki so se po potrebi posvetovali tudi s starimi deželani, ki so poznali razmere na terenu (sodobne “ekspertne skupine”). Pogajalce so imenovali mestni oblastniki, ki so se občasno dogovarjali med seboj tudi neposredno v prisotnosti javnosti ("premierski” dogovor). Kot nepristransko pričo so lahko v dogovor pritegnili še ugledno tretjo osebo, npr. podestata drugega mesta. Včasih je o meji odločal z obeh strani sprejemljiv posrednik-mediator. Redko - kot v primeru Pirana in Izole 1285 - je spor prerasel sporazumno sposobnost sprtih strani in je morala posredovati višja oblast, v omenjenem primeru beneški dož. Za reševanje spora je imenoval tuje razsojevalce - podestate sosednjih mest (“arbitražni sporazum”).

60 Gerd Althoff, "Genugtuung (satisfactio). Zur Eigenart gütlicher Konfliktbeteilegung im Mittelalter", v: Modernes Mittelalter. Neue Bilder einer populären Epoche, ur. Joachim Heinzle, Frankfurt am Main-Leipzig 1994, 247-265. 


\section{Povzetek}

Raziskava temelji na ohranjenih rokopisih piranske izpostave Pokrajinskega arhiva Koper iz 13. in prvih desetletij 14. stoletja, ki opisujejo reševanje ozemeljskih sporov in določanje mejà srednjeveškega Pirana s sosedi. Sodeč po ohranjenih zapisih o mejnih sporih in dogovarjanjih s sosednjimi mestnimi naselbinami, se je Piran največkrat soočal s sosednjo Izolo, sledile so Buje, občasno pa je bilo potrebno reševati tudi mejna vprašanja z Umagom. Pristopi, in rešitve ki so jih pri določanju medsebojnih razmejitev uporabljale sprte strani, so bili že pred stoletji primerljivi s sodobnimi: mestne državice so v medsebojnih dogovorih že v srednjem veku poznale takó skupine pogajalskih izvedencev (današnje ekspertne skupine), kot odločanje s pomočjo izbranih razsodnikov-mediatorjev in zunanjih arbitrov, pa tudi dogovore na "premierski" ravni (mestnih glavarjev). Opisu okoliščin, v katerih je prihajalo do podrobnejšega določanja mejà in razčiščevanja vprašanj v zvezi z njimi, sledi primer srednjeveškega opisa (piranskih) komunalnih mejà, nato pa so podrobneje predstavljeni zapisi, ki so nastali v zvezi z razmejitvami med Piranom in Bujami.

\section{Sporazumi o granicama srednjovjekovnih gradskih teritorija (Piran i njegovi susjedi) Darja Mihelič}

\section{Sažetak}

Istraživanje se zasniva na sačuvanim rukopisima piranske podružnice Pokrajinskog arhiva u Kopru iz 13. i prvih desetljeća 14. stoljeća koji opisuju rješavanje zemljišnih sporova i određivanje međa srednjovjekovnoga Pirana sa susjedima. Sudeći po sačuvanim zapisima o graničnim sporovima i dogovaranjima sa susjednim naseljima, Piran se je najčešće sukobljavao sa susjednom Izolom, slijedile su Buje, a povremeno je bilo potrebno rješavati i granična pitanja s Umagom. Pristupi i rješenja koje su pri određivanju međusobnih razgraničenja upotrebljavale zavađene strane prije više stoljeća usporedive su s ovovremenima: gradske državice su u međusobnim dogovaranjima već u srednjem vijeku poznavale kako skupine pregovaračkih vještaka (današnje "stručne skupine"), tako i odlučivanje pomoću izabranih sudaca-posrednika i vanjskih arbitara, a također i dogovore na "premijerskoj" razini (mjesnih poglavara). Opisu okolnosti u kojima je dolazilo do podrobnijega određivanja međa i raščišćavanja pitanja vezanih uz njih slijedi primjer srednjovjekovnoga opisa (piranskih) komunalnih međa, a potom su podrobnije predstavljeni zapisi koji su nastali u vezi s razgraničenjima između Pirana i Buja.

\section{Gli accordi sui confini dei territori cittadini medievali (Pirano e i suoi vicini) \\ Darja Mihelič}

\section{Riassunto}

La relazione si basa sui manoscritti del XIII e primi decenni del XIV secolo custoditi presso la sede piranese dell'Archivio regionale di Capodistria incentrati sulla soluzione di contese territoriali e sulla determinazione dei confini tra la Pirano medievale e le città limitrofe. A giudicare dalle fonti conservate sulle contese riguardanti i confini, Pirano si è per lo più scontrata con la vicina Isola, seguita da Buie e qualche volta è stato necessario risolvere anche le questioni di confine con Umago. Gli approcci e le soluzioni applicate secoli fa 
dalle parti contrastanti per determinare le delimitazioni comuni, sono comparabili a quelli contemporanei: già nel medioevo gli staterelli cittadini negli accordi reciproci conoscevano le prerogative sia dei gruppi di esperti in trattative (i "gruppi professionali" contemporanei) sia delle decisioni prese con l'aiuto di giudici-intermediari ed arbitri esterni scelti, come anche degli accordi presi a livello di "primi ministri" (capi locali). Alla descrizione delle circostanze in cui si arrivava ad una definizione più attenta dei confini e del chiarimento di questioni ad essi legate, seguono un esempio di descrizione dei confini comunali (piranesi) ed una presentazione più accurata di documenti redatti in occasione della delimitazione tra Pirano e Buie.

\section{Border negotiations on medieval town districts (Piran and its neighbours) \\ Darja Mihelič}

\section{Summary}

The research describes settlements of territorial and border disputes of medieval Piran and the neighbouring urban settlements in north-western Istria. It draws on the preserved manuscripts kept by the Piran Branch of the Regional Archives Koper dating back to the $13^{\text {th }}$ and the first decades of the $14^{\text {th }}$ century. Most charters were published by Camillo De Franceschi, one by Pietro Kandler, and a few were left unpublished. Judging from the preserved records on border disputes and negotiations conducted with its neighbours, Piran was most often at odds with Izola and Buje, and occasional border disputes would also arise in its relations with Umag. The description of situations that led to the specification of borders and settlement of related questions is followed by an example of a medieval description of (Piran) communal borders, which is followed by detailed descriptions related to border delimitations between Piran and Buje. The findings arising from the border settlement examples under discussion shed light on the compositional and spatial structure of medieval Istrian urban settlements that were not confined to the urban core but included broader agrarian surroundings. In this framework they developed - despite being subject to Istrian authorities - their own administration and judicial system, and constituted complete city states living side by side in the urban environment of northwestern Istria. They rigorously protected their territory and borders. Any breach of border by neighbouring communes led to disputes that were settled by mutual negotiations. The latter were conducted by selected representatives and with the assistance of superior Istrian authorities or secular and ecclesiastical lords. Customary approaches to border settlements were comparable to modern ones: medieval city states already employed groups of negotiation authorities (present "expert groups"), decision-making with the aid of selected arbiters-mediators and external arbiters, as well as agreements at "prime-ministerial" level (city chieftains). 
